\title{
An interdisciplinary response to contemporary concerns about brain death determination
}

Ariane Lewis, MD, James L. Bernat, MD, Sandralee Blosser, MD, Richard J. Bonnie, LLB, Leon G. Epstein, MD, John Hutchins, JD, Matthew P. Kirschen, MD, PhD, Michael Rubin, MD, MA, James A. Russell, DO, Justin A. Sattin, MD, Eelco F.M. Wijdicks, MD, PhD, and David M. Greer, MD, MA

Neurology ${ }^{\circledR}$ 2018;90:423-426. doi:10.1212/WNL.0000000000005033

\author{
Correspondence \\ Dr. Lewis \\ ariane.kansas.lewis@ \\ gmail.com
}

\section{MORE ONLINE}

ค Podcast

Dr. Andy Schomer

interviews Dr. Ariane Lewis about her paper on brain death.

NPub.org/6wum9n

From the Departments of Neurology and Neurosurgery, Division of Neurocritical Care (A.L.), NYU Langone Medical Center, New York, NY; Department of Neurology (J.L.B.), Dartmouth-Hitchcock Medical Center, Lebanon, NH; Pittsburgh Critical Care Associates (S.B.), PA; Schools of Law, Medicine, and Public Policy (R.J.B.), University of Virginia, Charlottesville; Department of Pediatrics, Division of Neurology (L.G.E.), Northwestern University Feinberg School of Medicine, Chicago, IL; American Academy of Neurology Deputy General Counsel (..H.), Minneapolis, MN; Departments of Anesthesiology and Critical Care Medicine, Neurology, and Pediatrics (M.P.K.), The Children's Hospital of Philadelphia, PA; Departments of Neurology \& Neurotherapeutics and Neurological Surgery (M.R.), UT Southwestern Medical Center, Dallas, TX; Department of Neurology (J.A.R.), Lahey Hospital and Medical Center, Burlington, MA; Department of Neurology (J.A.S.) University of Wisconsin, Madison; Department of Neurology, Division of Critical Care Neurology (E.F.M.W.), Mayo Clinic, Rochester, MN; and Department of Neurology (D.M.G.), Boston University School of Medicine, MA.

Go to Neurology.org/N for full disclosures. Funding information and disclosures deemed relevant by the authors, if any, are provided at the end of the article. 


\section{Glossary}

AAN = American Academy of Neurology; AAP = American Academy of Pediatrics; ANA = American Neurological Association; UDDA = Uniform Determination of Death Act.

The credibility of the medical profession is dependent on public trust. Considering the finality of a determination of death, there may be nothing more injurious to the social contract between physicians and patients than inaccuracy in its determination. Recently, the legitimacy of determination of death by neurologic criteria (brain death) has been publicly questioned in a number of prominent lawsuits, ${ }^{1-5}$ prompting concern that the public may develop, or already harbors, distrust in brain death determination.

While the foundations for these lawsuits are in part related to complex social, religious, psychological, and legal issues, the American Academy of Neurology (AAN) Ethics, Law and Humanities Committee, a joint committee of the AAN, American Neurological Association (ANA), and Child Neurology Society, and the AAN Practice Committee believed that it would be constructive for stakeholders in determination of brain death in the United States to convene at a quality improvement summit to address, and potentially correct, aspects of brain death determination within the purview of medical practice that may have contributed to these lawsuits. The goals of the summit were to discuss strategies to minimize perceived contemporary conceptual threats to brain death as a medical and legal determination in order to improve the public's trust, understanding, and confidence in use of neurologic criteria to determine death. Invitees included lawyers, ethicists, and physicians who represented all societies of practitioners involved in brain death determination. Attendees included adult neurologists, pediatric neurologists, intensivists, an anesthesiologist, a neuroradiologist, ethicists, and lawyers who belonged to, or represented, the AAN, American College of Radiology, ANA, American Society of Neuroradiology, Child Neurology Society, Neurocritical Care Society, and Society of Critical Care Medicine (appendix, http://links.lww.com/ WNL/A199). The group addressed the following issues: (1) the validity of the AAN's practice guideline for brain death determination; (2) the development of systems to ensure the accurate and consistent determination of brain death; and (3) the appropriate response to family objections to the use of neurologic criteria to determine death.

\section{History}

Due to developments in organ support that allowed ventilation and circulation to be maintained artificially for protracted periods despite devastating injury to the brain, an ad hoc committee at Harvard Medical School introduced the first criteria for brain death in the United States in $1968 .^{6}$ In the following years, multiple institutions produced their own guidelines on brain death determination, all of which were variations of the Harvard criteria. $^{7}$

By 1981, the medical community generally supported the concept of brain death. However, the idea that death could be declared based upon loss of brain function in an individual whose heart continued to beat was foreign to society as a whole. As a result, the President's Commission for the Study of Ethical Problems in Medicine and Biomedical and Behavioral Research (a committee composed of lawyers, philosophers, ethicists, religious officials, and physicians) was asked to consider whether death of the brain is indeed death of the person. After an extensive review, the Commission concluded that brain death should be endorsed as legal death, and produced the Uniform Determination of Death Act (UDDA), which states, "An individual who has sustained either (1) irreversible cessation of circulatory and respiratory functions, or (2) irreversible cessation of all functions of the entire brain, including the brain stem, is dead. A determination of death must be made in accordance with accepted medical standards." When defining "accepted medical standards," the authors of the UDDA chose not to specify clinical criteria and instead declared that brain death must be determined based upon standards "accepted by a substantial and reputable body of medical men and women as safe and efficacious for the purpose for which [they are] being employed." ${ }^{8}$ The UDDA, or a close approximation of it, has since been accepted as judicial or statutory law in every state. $^{9}$

In response to some specific questions the Commission posed about brain death, the AAN produced guidelines on brain death determination in adults in $1995 .^{10}$ These were subsequently updated in 2010 and endorsed by the Neurocritical Care Society, the Child Neurology Society, the Radiological Society of North America, and the American College of Radiology. ${ }^{11}$

Guidelines for determination of brain death in pediatric patients were published by the American Academy of Pediatrics (AAP) in 1987, and then updated in 2011 by the AAP in conjunction with the Child Neurology Society and the Society of Critical Care Medicine. ${ }^{12,13}$ They are similar, but not identical, to the adult guidelines. ${ }^{11,13,14}$

In 2008, the President's Council on Bioethics reevaluated the validity of determination of death by neurologic criteria. The prevailing opinion among Commission members was that 
there is a sound biological and philosophical basis for brain death. ${ }^{15}$

\section{The validity of the AAN's practice guideline for brain death determination}

The summit began with the questions of whether brain death represents death of a person and whether the AAN practice guideline is the accepted medical standard for brain death determination. While the attendees acknowledged that a minority opinion considers brain death to be a legal fiction and that death of the person does not occur until irreversible cardiopulmonary arrest, every attendee agreed that death determined by neurologic criteria is equivalent to death determined by cardiopulmonary criteria. Just as cardiopulmonary death is determined when there is irreversible loss of circulatory and respiratory function, brain death is defined by irreversible loss of consciousness and brainstem function leading to the inability to breathe independent of artificial support, and ultimately results in the demise and decay of all organ systems. Determination of death is based on loss of clinical function of the heart and lungs or the brain, and the demise of every neuron or myocardial cell is not required. ${ }^{16,17}$ The attendees further agreed that the 2010 AAN practice guideline is the contemporary paragon for brain death determination, as there have been no documented cases of recovery of neurologic function after determination of brain death provided the parameter is appropriately followed. ${ }^{11}$ The parameter is intentionally conservative and appropriately prioritizes specificity to avoid false-positive determinations.

\section{The development of systems to ensure that brain death determination is consistent and accurate}

Reviews of institutional protocols have demonstrated some inconsistency with the 2010 AAN practice guideline. ${ }^{11,18,19}$ Protocols have varying descriptions of prerequisites, ancillary testing, and apnea testing. ${ }^{18}$ Despite significant improvements in compliance with AAN guidelines in recent years, institutional protocols still deviate from the AAN practice guideline ${ }^{19}$ Reasons for these variances should be explored and education should be provided to promote standardization in order to avoid false-positive or false-negative brain death determinations. One method to generate consistency is for an appropriate regulatory authority such as the Joint Commission to review hospital protocols, similar to that which occurs during stroke center certification. ${ }^{18,20}$

Another barrier to performance of accurate determinations is the fact that qualifications for examiners and physician awareness of the intricacies of brain death determination vary. ${ }^{18,21}$ Frequent education and reeducation is warranted. This can be accomplished through simulation sessions. ${ }^{21}$ In addition, a credentialing program for physicians involved in brain death determination could help ensure that evaluations are performed consistently and accurately.

Finally, the attendees were concerned that the public trust in brain death determination could be adversely affected by the fact that criteria for determination of brain death in adult patients subtly differ from criteria for determination of brain death in pediatric patients. Guidelines for determination of brain death in pediatric patients were published in 1987 and updated in 2011 by the Society of Critical Care Medicine, the AAP, and the Child Neurology Society. ${ }^{12,14}$ Pediatric guidelines require performance of 2 brain death examinations and 2 apnea tests separated by an observation period, and include criteria for use of ancillary tests during brain death determination that differ from the adult practice guideline. ${ }^{11,14}$ The summit attendees resolved to work with the pediatric critical care and neurology communities to discuss these differences and facilitate, if possible, the creation of uniform criteria for determination of brain death in both children and adults. Attendees believed this could be achieved because the similarities between the criteria outweigh the differences.

\section{The response to objections to determination of death by neurologic criteria}

Although brain death is accepted by the ethical, medical, and legal communities as legal death, families sometimes object to determination of death by neurologic criteria due to moral or religious beliefs, hope that a patient will recover, or a lack of acceptance that a determination of brain death is the legal equivalent of a determination of cardiopulmonary death. These families often attempt to have a patient transferred to another facility to avoid determination of brain death and discontinuation of organ support. ${ }^{17,22-24}$ Management of these objections in both adult and pediatric patients varies by state, hospital, and practitioner. ${ }^{17,24}$ Failure to manage these tensions successfully has led to a number of prominent lawsuits in the United States in recent years in which families have objected to the validity and accuracy of determination of death by neurologic criteria. ${ }^{1-5}$ Although the President's Commission, in its influential 1981 report, sought to provide a template for the statutory definition of death throughout the country, defining death remains within the purview of individual states. Brain death is legally accepted as death in every state, but the language of state laws on determination of death is not uniform. ${ }^{25}$ Summit attendees voiced concern that lack of uniformity in both institutional policies and practices related to brain death determination and statutory definitions of death may, along with other factors, have contributed to the recent surge in lawsuits related to determination of death by neurologic criteria. If brain death is handled inconsistently by 
the medical or legal community, or handled differently from cardiopulmonary death, there could be erosion of public trust in the use of neurologic criteria to declare death.

\section{Discussion}

Despite the fact that brain death has achieved widespread medical and legal acceptance for nearly 50 years, medical, social, and legal controversies associated with determination of death by neurologic criteria persist. In order to improve public trust in the process and outcome of brain death determination, the summit attendees resolved to work with all stakeholders in brain death determination to identify how best to accomplish the following goals:

1. Advocate for uniform policies in all US health care institutions through implementation of regulatory oversight

2. Develop and promote education initiatives on brain death determination for members of the health care community, legal community, and the public in the United States

3. Promote brain death training and credentialing programs for all physicians doing brain death assessments to ensure brain death determinations are made based on established guidelines

4. Collaborate with the pediatric community to ascertain whether a singular standard for brain death determination can be developed

5. Advocate for a consistent legal approach to brain death determination in all 50 states

This document has been reviewed and endorsed by the AAN, AAP, American College of Chest Physicians, American College of Radiology, ANA, American Society of Neuroradiology, and Child Neurology Society. The Neurocritical Care Society endorses this document as an educational tool on the topic of brain death determination.

\section{Author contributions}

Ariane Lewis was responsible for conception and design, drafting the manuscript, and final approval of the manuscript. All other authors were responsible for conception and design, critical revision of the manuscript, and final approval of the manuscript.

\section{Acknowledgment}

The authors thank the American Academy of Neurology Ethics, Law and Humanities Committee and Practice Committee for sponsoring this summit and Karen Kasmirski and Sarah Nelson for their work organizing this summit.

\section{Study funding}

The summit was paid for by the American Academy of Neurology. As an employee of the American Academy of
Neurology, John Hutchins is paid by the Academy. Richard Bonnie receives a stipend to serve as a consultant to the American Academy of Neurology. No other authors received funding for their work on this article.

\section{Disclosure}

A. Lewis, J. Bernat, and S. Blosser report no disclosures relevant to the manuscript. $\mathrm{R}$. Bonnie receives a stipend to serve as a consultant to the American Academy of Neurology. L. Epstein reports no disclosures relevant to the manuscript. J. Hutchins is paid by the Academy. M. Kirschen, M. Rubin, J. Russell, J. Sattin, E. Wijdicks, and D. Greer report no disclosures relevant to the manuscript. Go to Neurology.org/N for full disclosures.

Received September 6, 2017. Accepted in final form November 29, 2017.

\section{References}

1. In Re: Guardianship of Hailu. 2015. p. 361 P.3d 5.

2. McMath vs. California. 2015. p. No. 3:15-06042 N.D. Cal.

3. Israel Stinson v. Children's Hospital Los Angeles. 2016. p. BS164387.

4. In Re: Mirranda Grace Lawson. 2016. p. CL16-2358, City of Richmond Circuit Court.

5. In Re: Allen Callaway. 2016. p. DG-16-08.

6. Ad Hoc Committee of the Harvard Medical School to Examine the Definition of Brain Death. A definition of irreversible coma: report of the Ad Hoc Committee of the Harvard Medical School to Examine the Definition of Brain Death. JAMA 1968;205 337-340.

7. Powner DJ, Snyder JV, Grenvik A. Brain death certification: a review. Crit Care Med 1977;5:230-233.

8. Defining Death: Medical, Legal and Ethical Issues in the Determination of Death [Internet]. Washington, DC: Georgetown University; 1981. Available at: hdl.handle. net/10822/559345. Accessed February 10, 2017

9. Burkle CM, Schipper AM, Wijdicks EFM. Brain death and the courts. Neurology 2011;76:837-841.

10. Wijdicks EFM. Determining brain death in adults. Neurology 1995;45:1003-1011.

11. Wijdicks EFM, Varelas PN, Gronseth GS, Greer DM. Evidence-based guideline up date: determining brain death in adults: report of the Quality Standards Subcommittee of the American Academy of Neurology. Neurology 2010;74:1911-1918.

12. American Academy of Pediatrics Task Force on Brain Death in Children. Guidelines for the determination of brain death in children. Pediatrics 1987;80:298-300.

13. Mathur M, Ashwal S. Pediatric brain death determination. Semin Neurol 2015;35 116-124.

14. Nakagawa TA, Ashwal S, Mathur M, Mysore M, Committee for determination of brain death in infants and children: guidelines for the determination of brain death in infants and children: an update of the 1987 Task Force Recommendations: executive summary. Ann Neurol 2012;71:573-585.

15. President's Council on Bioethics. Controversies in the Determination of Death: A White Paper by the President's Council on Bioethics. Washington, DC: President's Council on Bioethics; 2008.

16. Bernat JL. Controversies in defining and determining death in critical care. Nat Rev Neurol 2013;9:164-173.

17. Lewis A, Adams N, Varelas P, Greer D, Caplan A. Organ support after death by neurologic criteria: results of a survey of US neurologists. Neurology 2016;87: 827-834.

18. Greer DM, Wang HH, Robinson JD, Varelas PN, Henderson GV, Wijdicks EFM Variability of brain death policies in the United States. JAMA Neurol 2016;73: 213-218.

19. Wang HH, Varelas PN, Henderson GV, Wijdicks EFM, Greer DM. Improving uniformity in brain death determination policies over time. Neurology 2017;88:562-568.

20. The Joint Commission reports high interest in new certification program for comprehensive stroke centers. ED Manag 2012;24:127-129.

21. MacDougall BJ, Robinson JD, Kappus L, Sudikoff SN, Greer DM. Simulation-based training in brain death determination. Neurocrit Care 2014;21:383-391.

22. Lewis A, Varelas P, Greer D. Prolonging support after brain death: when families ask for more. Neurocrit Care 2016;24:481-487.

23. Burkle CM, Sharp RR, Wijdicks EF. Why brain death is considered death and why there should be no confusion. Neurology 2014;83:1464-1469.

24. Lewis A, Adams N, Chopra A, Kirschen M. Organ support after death by neurologic criteria in pediatric patients. Crit Care Med 2017;45:e916-e924.

25. Lewis A, Cahn-Fuller K, Caplan A. Shouldn't dead be dead? The search for a uniform definition of death. J Law Med Ethics 2017;45:112-128. 


\section{Neurology}

\section{An interdisciplinary response to contemporary concerns about brain death determination}

Ariane Lewis, James L. Bernat, Sandralee Blosser, et al.

Neurology 2018;90;423-426 Published Online before print January 31, 2018

DOI 10.1212/WNL.0000000000005033

\section{This information is current as of January 31, 2018}

\section{Updated Information \& Services}

Supplementary Material

\section{References}

\section{Citations}

Subspecialty Collections

\section{Permissions \& Licensing}

Reprints including high resolution figures, can be found at: http://n.neurology.org/content/90/9/423.full

Supplementary material can be found at: http://n.neurology.org/content/suppl/2018/02/27/WNL.0000000000005 033.DC1

This article cites 18 articles, 5 of which you can access for free at: http://n.neurology.org/content/90/9/423.full\#ref-list-1

This article has been cited by 14 HighWire-hosted articles: http://n.neurology.org/content/90/9/423.full\#\#otherarticles

This article, along with others on similar topics, appears in the following collection(s):

All Ethics in Neurology/Legal issues

http://n.neurology.org/cgi/collection/all_ethics_in_neurology_legal_iss ues

Brain death

http://n.neurology.org/cgi/collection/brain_death

Critical care

http://n.neurology.org/cgi/collection/critical_care

Information about reproducing this article in parts (figures,tables) or in its entirety can be found online at:

http://www.neurology.org/about/about_the_journal\#permissions

Information about ordering reprints can be found online:

http://n.neurology.org/subscribers/advertise

Neurology ${ }^{\circledR}$ is the official journal of the American Academy of Neurology. Published continuously since 1951, it is now a weekly with 48 issues per year. Copyright (C) 2018 American Academy of Neurology. All rights reserved. Print ISSN: 0028-3878. Online ISSN: 1526-632X.

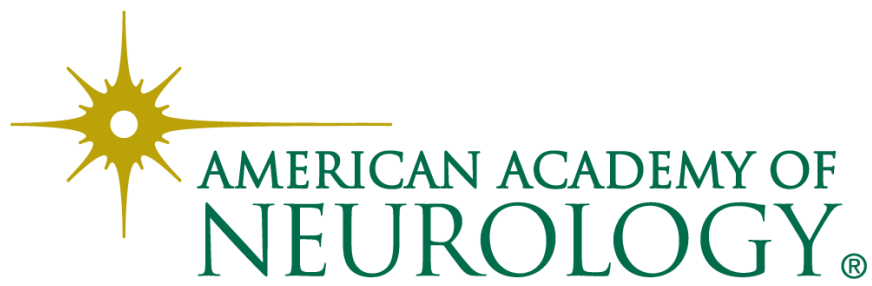

